\title{
APPRAISAL OF MULTILEVEL CAR PARKING FACILITY AT KG ROAD-CBD AREA, BENGALURU CITY
}

\author{
M R Rajashekara ${ }^{1}$, Mohammed Khalandar Khan ${ }^{2}$, Raghavendra R Kattimani ${ }^{3}$ \\ ${ }^{I}$ Professor \& pg co-ordinator, Civil Engineering Dept., Dayananda Sagar College of Engineering, Bengaluru, \\ Karnataka, India \\ ${ }^{2}$ Senior Traffic \& Transport Planner, M/S VOLUME, BENGALURU, KARNATAKA, INDIA \\ ${ }^{3}$ Student, 4th semester, Highway Technology, Civil Engineering Dept., Dayananda Sagar College of Engineering, \\ Bengaluru, Karnataka, India
}

\begin{abstract}
Due to the tremendous increase in Vehicular growth rate and city's population in recent time, terrific changes in land use is also observed. Traffic congestion on the roads is very rampant. Increased traffic congestion is making it tougher and tougher to get around on our regions roads. As there are more than 45.91 Lakh vehicles registered in Bengaluru as for 2013. Parking is one of the major problems that are created by the increasing vehicular traffic. It has an impact on transport development. The availability of less space in urban areas has increased demand for parking space especially in central business area, which affects the mode choice and has a great economic impact. Increasing parking demand together with limited parking supply and the absence of a parking regulation is an impediment to the smooth flow of traffic. The provision of multi-level parking system and other parking management strategies and their effective use emerges as the most viable initiatives in the large cities.

The scope of the study encompasses Zone wise On-street and Off-street Parking Surveys, Opinion survey, Road Inventory survey at and around KG Road MLCP which is one of the Busiest CBD areas in Central Bangalore. The relevant data were investigated and analysed. Based on the above data the Multi Storey Car parking system characteristics have been analysed and management has been assessed and parking management strategies or measures have been proposed.This Report highlights the surveys done, the analytical results, the future parking demand, constraint at the MLCPs with possible solutions and the justification on the need of MLCP at KG Road.
\end{abstract}

Keywords: MLCP, Appraisal, Demand Assessment, Economical Evaluation and Viability

\section{INTRODUCTION}

Parking is an essential component of the transportation system. It is increasingly becoming an important aspect of transportation planning. Parking facilities are a major cost to society, and parking conflicts are among the most common problems facing designers, operators, planners and other officials. Public parking spaces as one of the important parts of a modern urban transportation system, plays an important role in decreasing the load of heavy traffic. Suitable site selection for public parking spaces not only increases the parking efficiency, but it also decreases marginal car parking and so results in increase of streets' width and traffic fluency.

A systematic study of parking characteristic, demand and regulatory measures that are possible for controlling is of great help to a traffic engineers as well as town planner. Though there are parking lots available in these cities, the capacity of the parking lot is not sufficient to cater to the present demand and at the same time the location of the parking lot is questionable.

In the absence of adequate parking facilities, the vehicles are parked on the side of the street leading to a major bottleneck in the smooth flow of traffic. In addition, high population density, large number of pavement hawkers, sidewalk encroachments, heterogeneous nature of traffic and commercial area development along all the major roads have compounded the problem of congestion on the main as well as internal roads of these cities. Problems can be often defined either in terms of supply (too few spaces are available, somebody must build more) or in terms of management (available facilities are used inefficiently and should be better managed).

Parking management includes several specific strategies. When appropriately applied management can significantly reduce the number of parking spaces required in a particular situation, providing a variety of economic, social and environmental benefits. When all impacts are considered, improved management is often the best solution to parking problems.

\subsection{Parking Issues in Bengaluru City}

The vehicle population in Bengaluru has been steadily increasing with the pace picking up significantly since the eighties. The annual growth rate of vehicles at $10 \%$ per annum is more than the growth rate of population which is 
$3 \%$. Many city roads are already suffering from congestion. The problem of congestion is compounded by the fact that parking is free in Bengaluru and on-street parking is unregulated. As a result, parked vehicles take up precious road space leaving less road space for moving vehicles. Parking, both on-street and off-street occupies valuable urban land. In a way, investment on parking infrastructure is non-remunerative to the city from social, economic and environmental angles as ample parking encourages the use of automobiles. In a city where approximately about $45 \%$ of road users use public transport to commute, a large investment on creation of parking infrastructure to fulfil the requirement of automobile users for parking has no rationale. This is not to say that no off-street parking infrastructure needs to be created, the emphasis should be more on making optimum utilization of infrastructure that is already in place instead of merely and routinely adding to parking supply. In the absence of important measures like pricing of on-street parking and regulation of on-street parking, the mammoth parking lots would be under-utilized and thus, not viable.

As a response to the parking problems in Bengaluru, Bruhat Bengaluru Mahanagara Palike (BBMP) intends to develop multi-level parking facilities across Bengaluru in phased manner. It is envisaged that these proposed parking facilities would be developed either underground or would be multi-storied structures above the ground. It is further envisaged that where possible and necessary, parking space may be combined with commercial development to make the project as financially viable under a Public Private Partnership (PPP) model.

There are already developed MLCPs like the ones at Garuda mall, Kempegowda Shopping Centre (on PPP Model) and J.C road Multilevel Car Parking which are not utilized to their maximum capacity most of the days. Hence, to determine the causes behind the sub-optimal utilization of these MLCPs, a study at one of the location is carried out. This report pertains to the study of the KG road MLCP developed by BBMP.

The vehicular growth in Bangalore is very high as shown in the Fig 1.1.

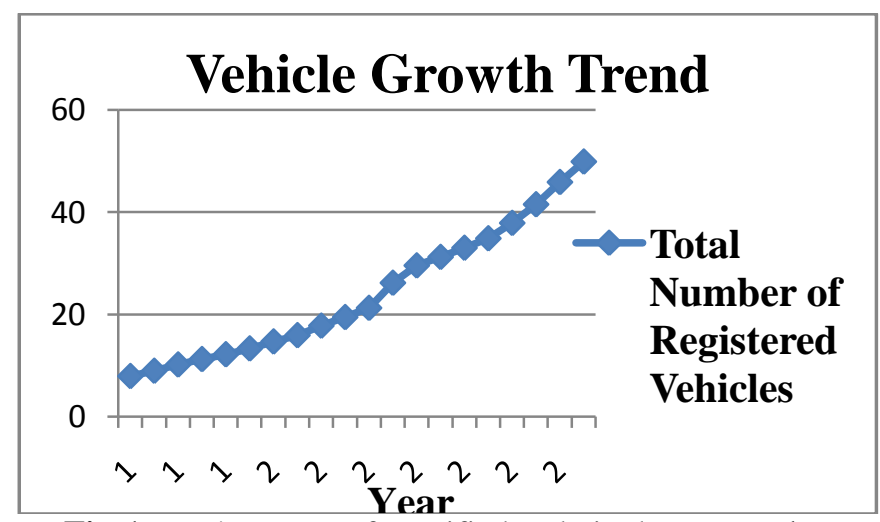

Fig-1Error! No text of specified style in document..1: Vehicle growths Trend in Bengaluru
According to the recent estimates, there are about 3.158 million 2-wheelers, 0.894 million Motor-cars, 0.151 Million auto-rickshaws or cabs, and 0.388 million other vehicles, totalling to around 4.156 million vehicles on road by 2012 and 4.591 for 2013 . The vehicular percentage break up is as shown in the Fig 1.2

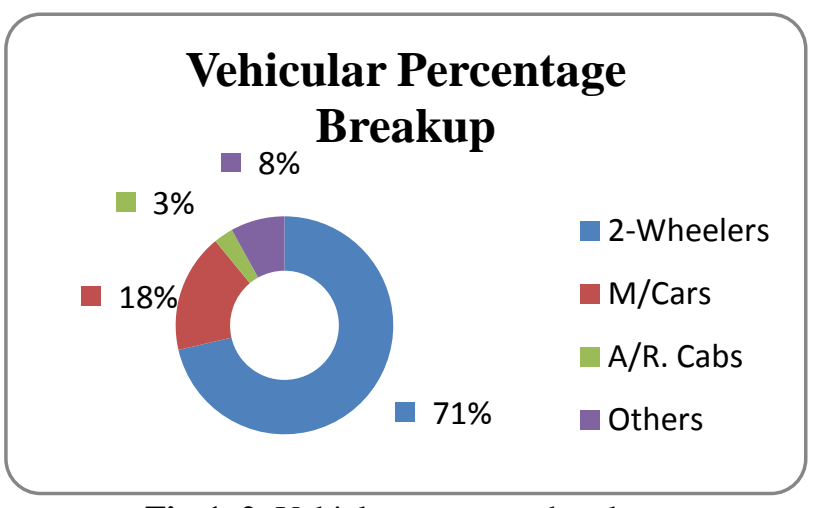

Fig-1. 2 :Vehicle parentages break up

\subsection{Scope of the Study}

- To conduct Site Reconnaissance, Parking and Traffic Volume Surveys

- To estimate parking, demand and supply in the catchment area.

- To estimate parking, demand and supply in the shopping mall.

- To suggest measures to increase the demand of parking at the existing facilities.

- Recommendations for the type of studies to be adopted for future proposals of MLCPs.

\subsection{Objective of the Study}

The study area situated in a commercially vibrant location attracts significant number of shoppers generating a sizeable parking demand. It has many movie screens which also attract trips. These factors combined with the commercial surroundings attract a customer and traveller base that has a preference for personalized mode of travel. With the increased use of personalized modes of transport, the parking demand is high.

BBMP had developed this MLCP on PPP model basis to provide public parking, due to its commercial viability. The MLCP with shopping mall did not have any Parking Demand Assessment study conducted prior to its construction thus resulting in irregular demand / supply of parking.

The objective of this study is to assess the existing parking demand and supply for the study area, to assess how the existing MLCP facility can be optimally used, the measures to improve vehicular circulation in and around the study area, and to identify other factors that might affect the parking demand. 


\section{LITERATURE REVIEW}

This chapter outlines the literature pertaining to the parking definition, parking surveys, parking policy, parking planning and management strategies. It also provides information of various parking management strategies used worldwide. Some of the successful case studies of implementation of parking planning and management studies are briefed.

\subsection{Introduction to Transportation Engineering}

Various aspects of parking related index are introduced as follows:

- Parking accumulation: It is defines as the number of vehicle parked at a given instant of time. Normally this is expressed by accumulation curve. Accumulation curve is a graph obtained by plotting the numbers of bays occupied with respect to time.

- Parking volume: Parking volume is the total number of vehicle parked at a given duration of time. This does not account for repetition of vehicles. The actual volume of vehicles entered in the area is recorded.

- Parking load: parking load gives the area under the accumulation curve. It can also be obtained by simply multiplying the numbers of vehicles occupying the parking area at each time interval with the time interval. It is expressed as vehicle hour.

- Parking Index = Parking volume/Number of bays available. This can be expressed as number of vehicles per day per time requirement.

- Parking duration: The length of time spent in a parking space.

\subsection{Policy Paper for Parking in the Bangalore Metropolitan Region}

\subsubsection{Objectives:}

1) To effectively manage parking demand through a series of measures which include dynamic pricing of parking, congestion tax, proof of parking (vehicle-parking certificates) etc.

2) To effectively manage parking supply through construction and maintenance of off-street and onstreet parking lots, park and ride facilities in important transit centres and effective regulation of on-street and off-street parking etc.

3) To design parking infrastructure keeping in view the needs of physically handicapped, nonmotorized transport etc.

4) To design and construct truck terminals at vantage points to prevent haphazard parking of trucks on the arterial roads.

\subsubsection{Parking Management Plan for the City:}

The parking management plans for the city will take into account the density of economic activity, access to public transport, road congestion etc. The ABC location policy tried successfully in other cities will be adopted:

"A" category locations: Places most accessible by public transport. Pricing and regulation of on street parking in such areas should be stringent.

"C" category locations: Less stringent norms as connectivity by public transport is poor.

"B" category locations: Between A and C. Norms to be fixed accordingly.

On-street parking spaces shall be earmarked only for shortterm use such as for delivery of goods and shopping and shall be for short durations. A list of roads where on-street parking is completely prohibited and where it is allowed will be prepared and notified. The parking ban will be strictly enforced through a system of checks (through installation of CC T.Vs etc.) and hefty fines. On-street parking will be allowed only if carriage width is sufficient. The maximum duration allowed for on-street parking would be not more than two hours as a general principle, especially in " $A$ " category locations. There will be complete ban of on street parking of larger vehicles. Meters will be used to measure even small increments of time used for parking system and a system of proportionate charging of time used for parking will be introduced to increase parking turnover. Designated auto stands will be developed to prevent spill over into the roads.

In the short term parking supply also needs to be augmented especially through off-street parking lots. An inventory of the off-street parking infrastructure available in the city (both Government and Private owned) in each area/zone will be prepared and parking demand assessed through detailed studies. Off-street locations will be identified for surface parking and for construction of multi-level parking lots.

Off-street parking lots can either multi-level or surface i.e., vacant site/private plots. These plots can also provide space for night parking i.e., off-street residential parking where either space is not available at individual homes or the roads are too narrow to permit entry of vehicles.

The policy aims to introduce an incentive scheme to encourage owners of vacant plots (Private, Government etc.) to lease their plots to the local body for off-street parking for mutually agreed periods and mutually agreed arrangements. The scheme would have exit clauses that facilitate an owner of the plot to opt-out of such arrangement as and when he requires the land for construction. A licensing scheme will be introduced to license all such off-street parking lots. The local body shall notify these lots. Approximate signage should be available to direct people to them.

Scheme for shared parking will be introduced in certain areas especially where mixed-land use exists i.e., parking lot of a restaurant, which may be fully occupied during evenings and partly vacant during day could be used for office parking. Office parking lots could be used for parking 
by shopping public during evenings. Parking lots of malls, which may be only partly occupied during weekdays, could be used for long stay parking by nearby offices. The policy will also endeavour to promote construction of parking lots on PPP mode. Whenever local body proposes multi-level car parking, it shall be supported by studies that assess the requirement for parking/ parking demand in the hinterland of such facility.

Mechanized parking lots shall be set up where it is not possible to earmark off-street parking lots at a reasonable distance and where the roads are too narrow and congested to permit on-street parking. Separate parking lots will also be insisted for water tankers, private buses etc., to prevent them being parked on the streets. In order to prevent haphazard stopping of private buses to facilitate pick up and alighting of passenger, specific stretches will be identified for this purpose where private buses could stop. Construction of Private bus stands will be encouraged on PPP model at specified locations to find a long-term solution to this problem.

\section{APPROACH AND METHODOLOGY}

This section illustrates the approach and methodology which has been followed to undertake the study. In a study of this type, the first step is to analyse the existing parking characteristics of the study area. Parking surveys are intended to supply the information needed for assessment of parking demand and supply for a study area.

\subsection{Site Reconnaissance Survey}

In order to understand the site, a site reconnaissance survey is essential. This survey was done for the study area to capture the road characteristics like available ROW and carriageway width. Land use in the site vicinity was surveyed. Major establishments and trip generators were identified. Traffic circulation and accessibility to the site was assessed. Other relevant issues like encroachment, unauthorized parking, unused bus stops etc. were flagged, and accordingly issues were identified.

\subsection{Parking Surveys:}

The following surveys were conducted for understanding the parking characteristics, estimation of demand and supply for parking and for projecting the future parking demand.

- On-street parking surveys to study the parking characteristics and demand along with roadside accumulation survey for the parked vehicles were done.

- Off- street surveys i.e. at MLCP to analyse parking demand and its characteristics.

- Opinion surveys elicited opinion of the users about the facilities available for parking and their willingness to pay the fee for using the facility. The opinion survey also reveals the extent of suppressed parking demand.

- Inventory surveys were conducted to collect the potential of the existing facility in terms of available space, road characteristics, type of parking, land use of the location, etc.

The data has been analyzed making use of PHP programming to calculate the Duration and amount of each vehicle parked in MLCP further the data is analyzed by entering the data in proper format in the form of time and count which is given as 1 . Next step is to pivot the table in excel and filtering the vehicle code wise and forming a matrix which put in template to give the results presented in terms of vehicle accumulation graphs and duration diagrams. Different Equivalent Car Spaces (ECS) values were adopted for different vehicle types and are given in Table 3.1. The ECS values were arrived based on the size of various vehicles and compared with that of passenger cars. The duration of vehicles parked was classified into different categories as given in Table 3.2

Table-3.1 PCE values for Different Type of Vehicles

\begin{tabular}{||l|l|l||}
\hline Sl. No. & Vehicle Category & ECS \\
\hline 1 & Car & 1.0 \\
\hline 2 & Two Wheelers & $0.25^{*}$ \\
\hline 3 & Bus & 2.5 \\
\hline 4 & Trucks & 2.5 \\
\hline 5 & LCV & 1.75 \\
\hline 6 & Auto & 0.5 \\
\hline 7 & Cycles & 0.1 \\
\hline 8 & Cycle Rickshaw & 0.8 \\
\hline 9 & Carts & 3.2 \\
\hline
\end{tabular}

Table-3.2 Classification of Duration of Parking

\begin{tabular}{|l|l|l|}
\hline \multicolumn{2}{|l|}{ Parking Duration } \\
\hline $\begin{array}{l}\text { SI } \\
\text { No. }\end{array}$ & Duration of Parking & Designation of Parking \\
\hline 1 & Up to 0.5 Hour & Quick Parkers \\
\hline 2 & B/w 0.5 Hour and 1 Hour & Short Stay Parking \\
\hline 3 & B/w 1 Hour and 2 Hours & Medium Stay Parking \\
\hline 4 & B/w 2 Hour and 3 Hours & Long Stay Parking \\
\hline 5 & B/w 3 Hour and 4 Hours & Very Long Stay Parking \\
\hline 6 & $>4$ Hours & Very Long Stay Parking \\
\hline
\end{tabular}

\subsection{Opinion Survey}

Opinion surveys were conducted to elicit the opinion of the users about the facilities available for parking and about their willingness to pay the fee for using the proposed facility. The survey was done on a random sample basis during peak and off- peak periods. Users of the parking lot were interviewed and responses elicited on problems in existing parking facility, origin, destination, distance travelled, frequency of the visit, purpose of the visit, parking duration, occupancy, opinion about the existing parking rate with respect to existing facility, opinion of the user about the parking charge system and willingness to pay. This survey was conducted on both weekdays and weekends. 
A total of 1000 samples, 200 in each zone and 200 at respective MLCP were collected. Outcome of the survey include identification of influence area of the market, frequency of the visit, purpose of the visit, problems with existing parking facility, occupancy rate, opinion about the existing parking rate and about the future parking charge system with improved parking facility.

\subsection{Parking Place Inventory}

Inventory surveys are intended to collect the potential of the existing facility in terms of available space, road characteristics, type of parking, land use, etc. The details such as total length, length available for parking, number of parking bays available, type of parking, vehicle type parked (authorized or unauthorized), parking fee, land use along the road, etc., type of parking (includes parallel, and perpendicular), type of land uses such as commercial, residential, institutional, recreational, religious, industrial etc. were collected. Data on road characteristics was also collected. It includes paved roadway width, shoulder width and type, footpath width and type, edge to edge distance between footpath and shop, and encroachment.

\subsection{Data Analysis}

From the data collected following parameters are evaluated:

- Parking Duration: Parking Duration: The Length of time spent by vehicles in a parking space.Manual calculation of the parking duration and other characteristics is tedious hence The collected data is analyzed using an PHP (Personal Home Page or Hypertext Preprocessor) programming language which is easy to learn and analysis can be done in a very short time compares when compared to other programming languages like $\mathrm{C}, \mathrm{C}++$ etc. in the present case. Hence the data is analyzed using php programming and the results were used for the further calculations using MS Excel.

The Figure 3.1 shows the Data flow Diagram of the programming and Figure $\mathbf{3 . 2}$ shows the flow diagram for the display of complete list of Vehicle registration number, entry time entry date, exit time, exit date, parked duration and the amount charged..

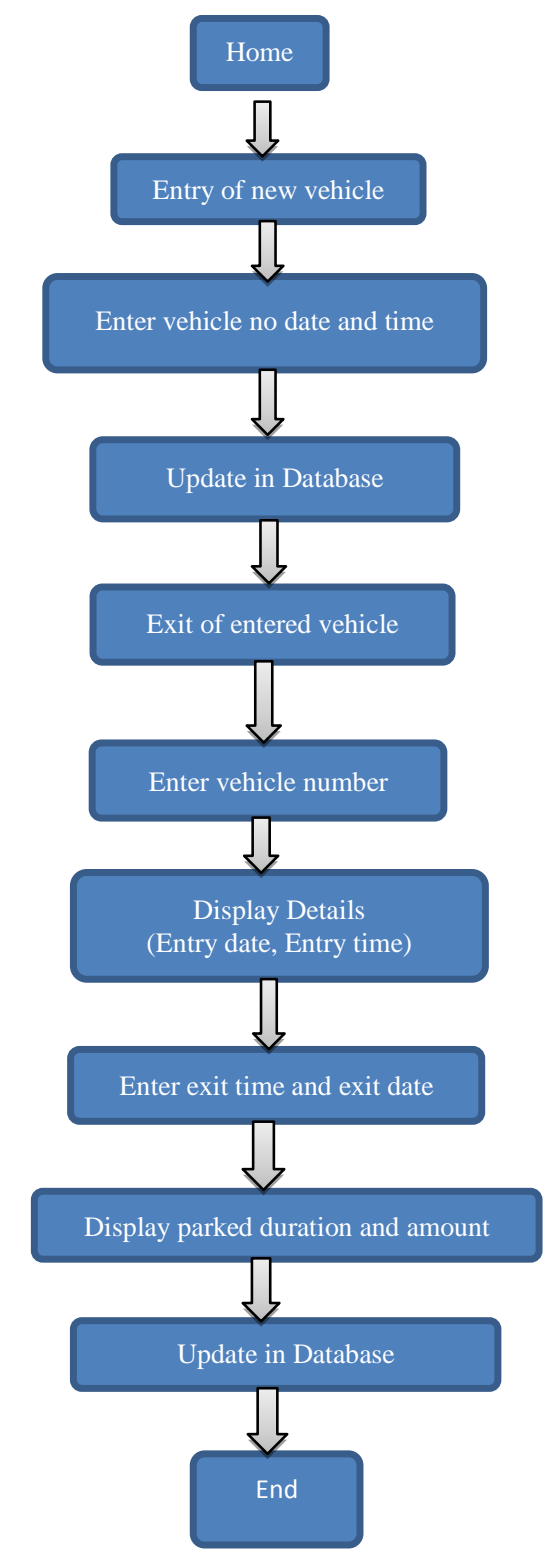

Fig-3.1:Data flow diagram of the programming to calculate the parked duration and the Parking charges. 


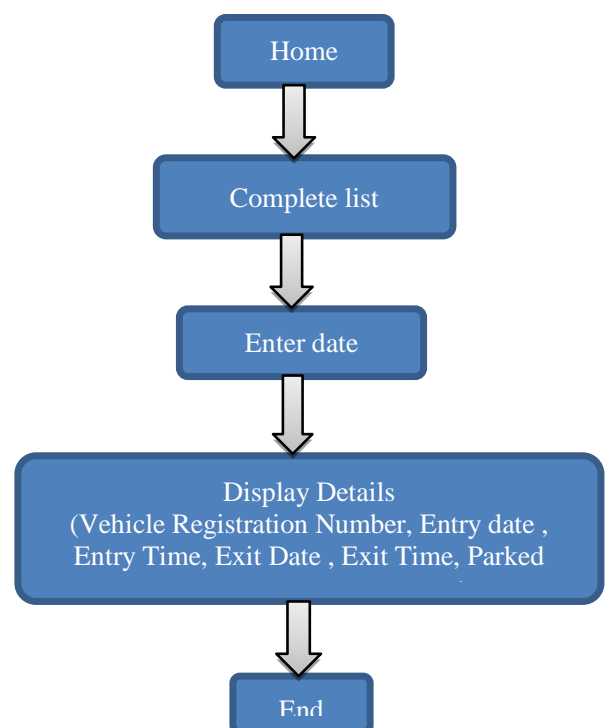

Fig- 3.2:Data flow diagram to Display the Complete Parked vehicles history

- Parking Volume: The number of vehicles parking in a particular area over a given period of time.it is usually measured in vehicles per day.

- Parking Accumulation: The Total number of vehicles parked in an area at a specified moment. The curve of parking accumulation for a typical day is as shown in figure below

- Parking Load: The area under the parking accumulation curve during a specified period.

- Parking index: It is the ratio of parking accumulation by the parking capacity of the survey area, and is expressed in percentage. It gives an aggregate measure of how effectively the parking space is utilized.

\section{Parking Index $(\mathbf{P I})=($ Parking Accumulation/Parking Capacity) x100}

- Parking Occupancy- Number of ECS occupied as a percent of total available spaces.

- Parking Turn-over: The rate of the usage of the available parking space. Thus if there were 10 parking spaces used by 100 vehicles in a period of say 12 hours, then

\section{Parking turn-over $=100 / 10$ vehicles per space in a period of 12 hours.}

- Parking demand analysis: Parking demand refers to the amount of parking that is estimated to be used at a particular time or place. It is a critical factor in evaluating parking problems and solutions. Parking demand is affected by vehicle ownership, trip rates, mode split, duration ,geographic location,the quality of travel alternatives, type of trip. In many ways, estimating parking demand is a value judgment, rather than a technical exercise.
- Parking supply analysis: The study of a parking supply is an inventory of the existing supply. By examining the parking supply and comparing it to the parking demand, we quantify the parking surplus or deficit that exists or potentially will exist with future development.

- Parking management by other methods: There are many reasons to use management strategies that result in more efficient use of parking resources, in order to address parking problems, retain existing parking with standard specification, one day parking on alternate day, paid parking and offstreet parking/multi storied parking

\section{DATA ANALYSIS AND RESULTS}

\subsection{Site Reconnaissance Survey}

From The Site Reconnaissance survey conducted the following parameters were obtained

\subsubsection{Study Area and Site Plan}

Kempegowda Maharaja MLCP (henceforth referred to as the Site) is located on the Left side of KG Road toward Majestic (KBS) and KG circle under Upper Pete police station limits. The Site in a broad sense is located in a predominantly commercial locality. Towards the North east side of the Site is famous Sagar theatre dead opposite to MLCP. West of MLCP is the Hindustan Arcade and to the East is the Hospital cross road with fully commercial land use. The location of Site is as shown in Figure: 4.1

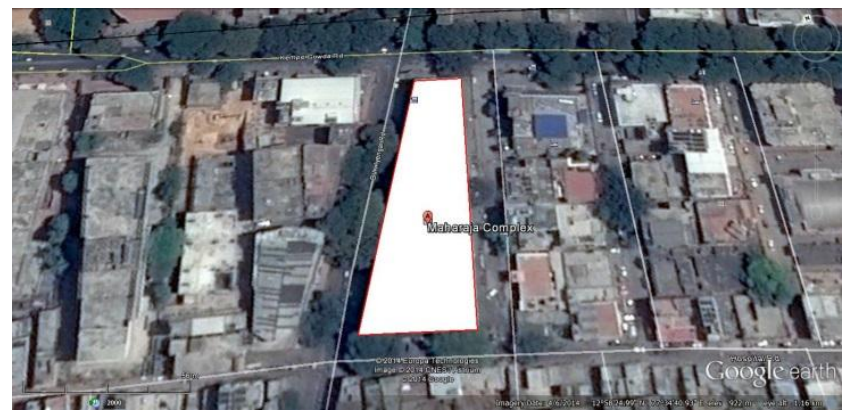

Figure 4.1 Site: KG road MLCP

\subsubsection{Access Roads to Site}

The Main road access to the Site is from B.V. Iyengar road and there is entry point from the cross road behind the MLCP for the basement and MLCP parking. KG Road is a one way road from City to KBS (majestic) at adjacent to MLCP running generally in the west direction. B.V.K Iyengar Road running generally in the South-North direction is a divided two ways. Kalidas marg which is one way, adjacent to Sagar theatre and Hanumantappa road connecting to $\mathrm{KG}$ road from North side of the side with Palace road a main road connecting. From the south side of the site which connects are hospital cross roads, Avenue road as an important main road with B.V.K Iyengar road a main through for the MLCP KG road, Kalidas road, Hanumantappa road with Hospital cross roads are 
complimentary one way roads and B.V. Iyengar road, Palace road, Avenue road are two way roads.

The roads connecting the Site from all quarters, in other words, the access roads to the Site are indicated in Figure: 4.2.

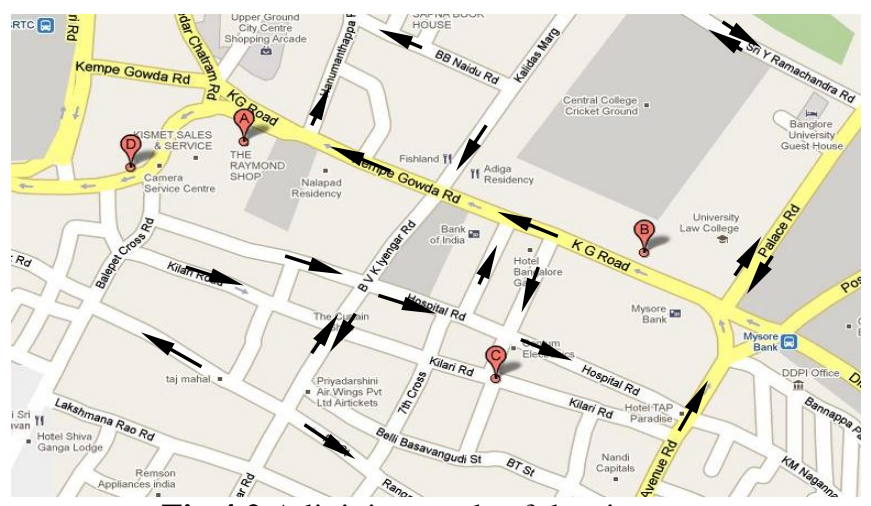

Fig 4.2 Adjoining roads of the site area

\subsubsection{Zoning of the Study Area}

The radial influential area of 500 meters from the Site was considered for the study was then divided into four zones as shown in the Figure 4.3: The four zones are described as follows:

Zone 1: part of Danvantri road and $\mathrm{Kg}$ road, subedar road, Hanumantappa road, B.B Naidu cross road to Kalidas Marg (left).

Zone 2: Part of KG road, Ramachandra road, palace road, Kalidas Marg (right).

Zone 3: Part of KG road, cross roads such as kileri road, Dk lane, hospital road, huriupete road connecting B.V. Iyengar road and Avenue road to the west and east of the MLCP respectively.

Zone 4: KG road, Balepete cross roads, park road, part of tank bund road, Laksman roa road, kileri cross road.

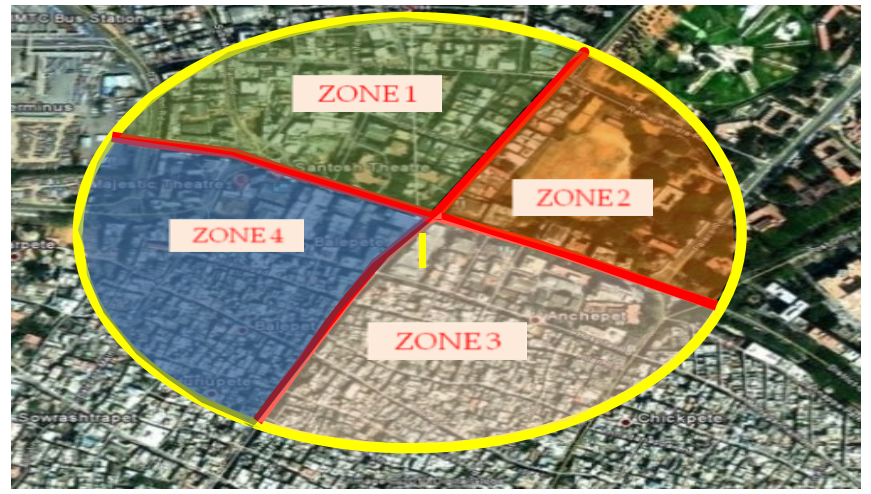

Fig 4.3 Study Area: radius of 500 meters from the site

\subsection{INVENTORY SURVEYS}

\subsubsection{Land Use Pattern}

This MLCP is located at the heart of the city and an important shopping hub for many bangaloreans so the site area comprises mainly of commercial complexes and movie theatres. The area is close to major transport modes of the city say Kempegowda bus stand (KBS) and central railway station. Many commercial establishments and business centres have come up in this area in due course of time making it a predominantly business precinct of Bengaluru. The density of traffic varies with the variation of land uses and the time of the day. Land use transformation has been slow in this stretch. The land use breakup for the area is shown in Table: 4.1 and the land use distribution is as shown in Figure: 10.

Table 4.1: Land Use details at the vicinity of $\mathrm{KG}$ road MLCP

\begin{tabular}{|l|l|}
\hline Type & Percentage \\
\hline Commercial & $\mathbf{7 8 \%}$ (Blue) \\
\hline Open Space & $\mathbf{4 \%}$ (Green) \\
\hline Residential & $\mathbf{2 \%}$ (Red) \\
\hline Mixed & $\mathbf{7 \%}$ (Blue) \\
\hline Public buildings & $\mathbf{9 \%}$ (Red) \\
\hline Total & $\mathbf{1 0 0}$ \\
\hline
\end{tabular}

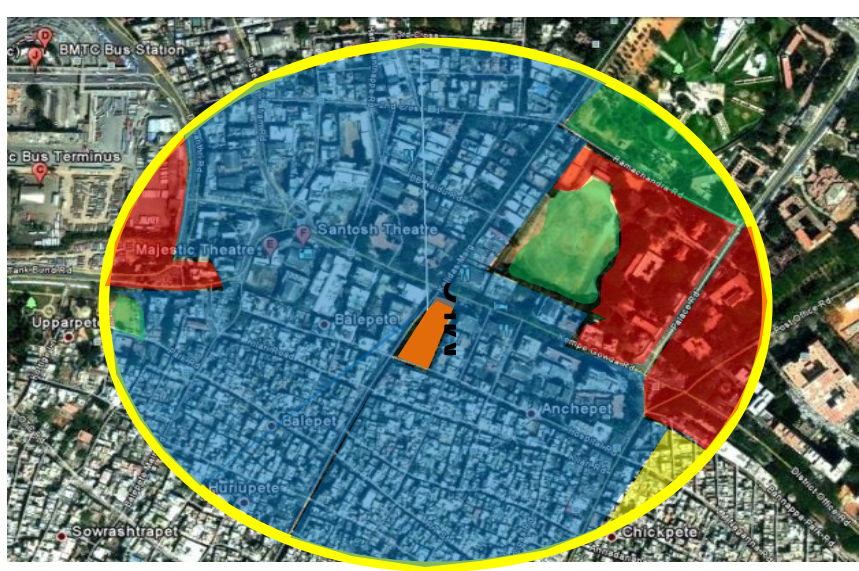

Fig 4.4 Land Use as per Zones

\subsubsection{Traffic Circulation in the Study area}

The vehicular flow on KG road is one way starting from Mysore bank circle at the east end of $\mathrm{Kg}$ road intersection. Kalidas marg which comes and joins at KG circle at north of the MLCP is one way. B.V. Iyengar road is divided two way traffic, passing by MLCP at south west direction.

The remaining cross roads surrounding the site are one way and almost all the major roads at the vicinity are either partially or fully one way. The detail traffic flow diagram is as shown in the Figure: 4.2 


\subsubsection{Major issues near the Site area}

- On-street parking of four wheelers on the Hanumantappa cross road with $6 \mathrm{~m}$ carriageway two way and the surrounding roads causes problems to the moving traffic. Parking needs to be prohibited in this area.

- Unauthorized Parking of vehicles mainly cars came for the shops mainly commercial locality

- Two wheeler parking on Foot path at the end of the KG road causes inconvenience to the pedestrians.

- $\quad$ Entry and Exit of cars from MLCP during the peak hours leads to queuing of vehicle on Hospital road thus causing unnecessary delays.

- Auto stand at the junction has resulted in traffic chaos at the junction. Auto stand has to be designated to avoid traffic chaos.

- Illegal street hawkers and road side eateries have occupied major portion of foot paths and road width; the public is attracted thereby resulting in serious

\subsection{Parking Surveys and Parking Characteristics}

\subsubsection{Parking Supply}

The total on-street parking and off- street parking available is 474 and 666 ECS. Thus, the total supply of parking spaces is estimated at 1140. This includes all the parking spaces, both on-street and off-street in study area.

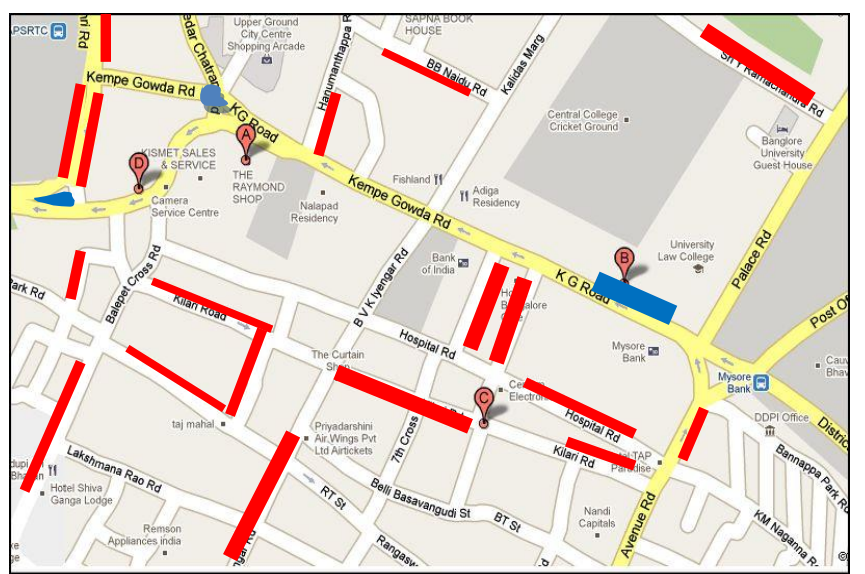

Fig 4.6 On-Streets and Off Street Parking

\subsubsection{Parking Volume}

\subsubsection{Zone Wise}

The total number of vehicles parked in an area at a particular time was counted i.e. the accumulation surveys were done for all Zones, for weekdays and weekend the result is given in Figure 4.7

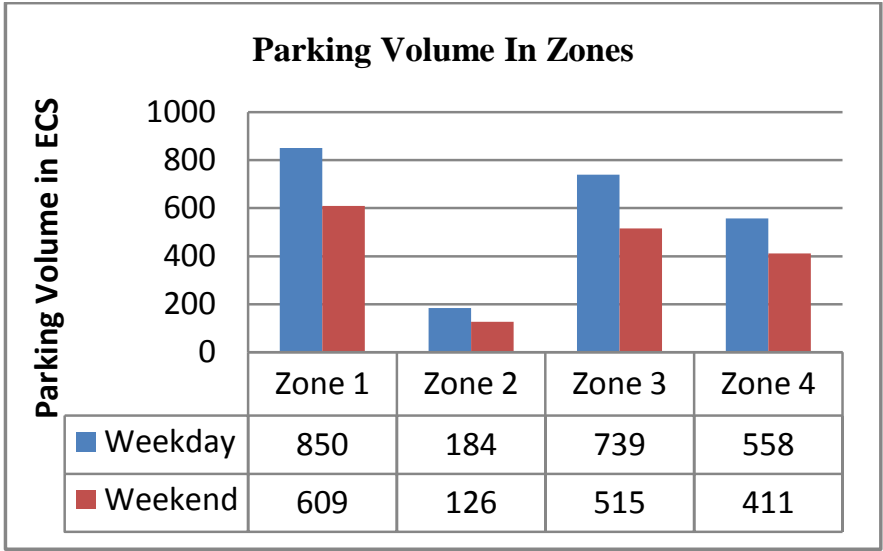

Fig 4.7 Graph Showing Parking volume in each zone wrt weekend and week day

\subsubsection{Parking Volume - at MLCP}

The total number of vehicles parked in an area at a particular time was counted i.e. the accumulation surveys at MLCP, for weekdays and weekend and is given in the table below and shown in the Figures:4.8

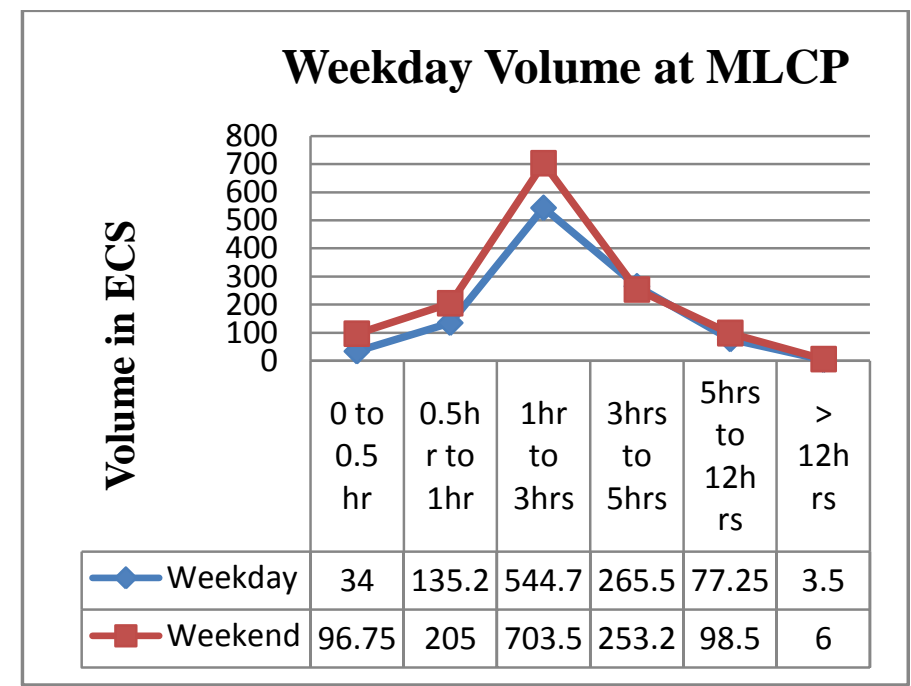

Fig 4.8 Weekday \& Weekend Parking Volume in ECS - at MLCP

\subsubsection{Parking Duration}

Parking duration is defined as length of time a vehicle spends in the parking space. Parking duration is illustrated for the weekdays and weekend in the following figures. The observations are shown in Figure 4.9 and Figure 4.10 


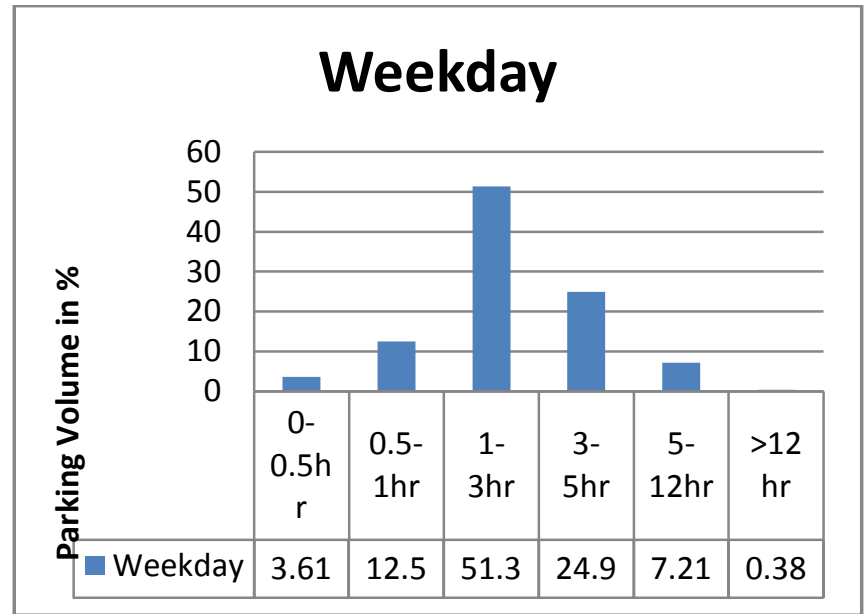

Fig 4.9 Weekday Parking duration at MLCP

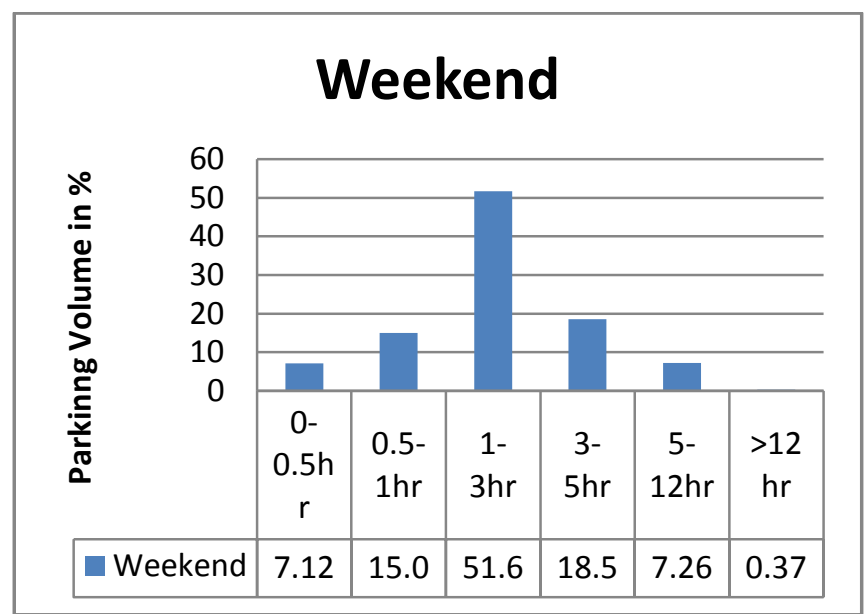

Fig 4.10 Weekend Parking duration at MLCP

\subsubsection{Summary of Existing Parking Demand in the vicinity MLCP}

Parking surveys, both on-street and off-street were conducted in the site vicinity. This was done to value the existing parking demand in the area, which would help in estimating the present parking demand and projecting the future parking demand in the area.

The analysis shows that the peak hour On-street parking demand in the vicinity is 2331 ECS. The authorized on- Street parking supply with respect to the roads under the usage of parking is about 640 ECS. Thus a gap of 1691 ECS is there. The gap could be higher because vehicles are crammed bumper to bumper at the parking locations and are also parked at unauthorized locations while supply calculation is based on existing norms and takes into account only the authorized parking spaces.

\subsubsection{Parking Accumulation at MLCP}

The total number of vehicles parked in an area at a particular time was counted i.e. the accumulation surveys at MLCP, for weekdays and weekend and is given in the table below and shown in the Figures 4.11

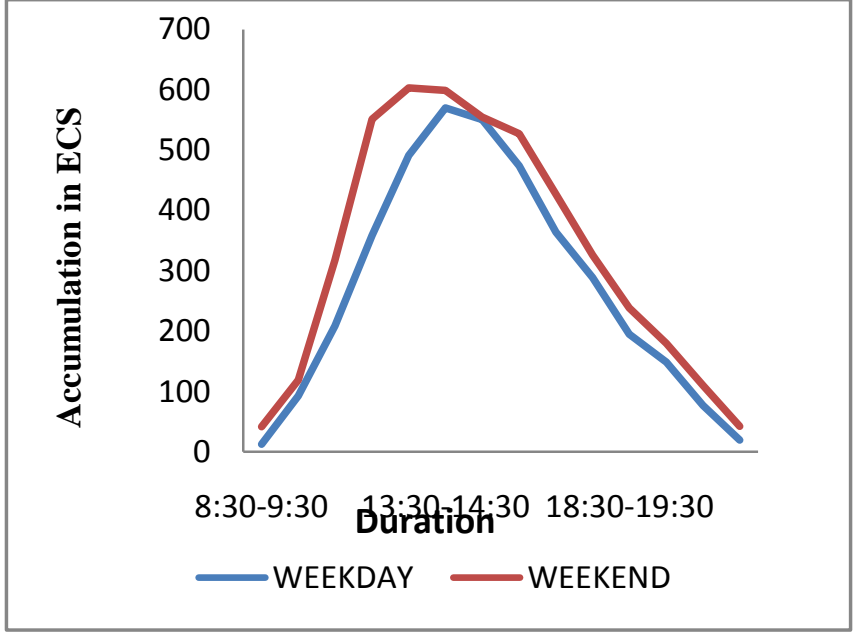

Fig 4.11 Variation of Parking Accumulation

\subsubsection{Parking Demand and Supply Gap}

Peak parking demand and supply observed at MLCP is from the primary parking surveys as given in

Table 4.2. Supply is calculated on the basis of parking norms and available type of parking style.

Table 4.2 Peak hour demand and supply gap @ MLCP

\begin{tabular}{|c|c|c|c|c|}
\hline & \multicolumn{2}{|c|}{ Peak hour(ECS) } & Gap & Turnove \\
\hline Day & Demand & Supply & Volume & (ECS) \\
\hline Weekday & 570 & 500 & -70 & 1054 \\
\hline Weekend & 603 & 500 & -103 & 1363 \\
\hline
\end{tabular}

It is observed that during the weekdays the average total gap between supply and demand is about 70 ECS and during the weekends the average gap is about 103 ECS during the peak hours. This shows that at any given time the parking slots at MLCP are utilized i.e. slots are not that vacant.

The total day's parking turnover was also done for 7 days from Monday to Sunday to know the actual turn over at the MLCP. The Total variation of the week can be obtained and the flow pattern of the parking can be known. The details are as shown in Table 4.3

\begin{tabular}{|c|c|c|}
\hline Si No & Day & $\begin{array}{c}\text { Turnover } \\
\text { (ECS) }\end{array}$ \\
\hline $\mathbf{1}$ & Monday & 998 \\
\hline $\mathbf{2}$ & Tuesday & 1034 \\
\hline $\mathbf{3}$ & Wednesday & 1054 \\
\hline $\mathbf{4}$ & Thursday & 1002 \\
\hline $\mathbf{5}$ & Friday & 906 \\
\hline $\mathbf{6}$ & Saturday & 1363 \\
\hline $\mathbf{7}$ & Sunday & 971 \\
\hline
\end{tabular}

Table 4.3 Variation of Turnover @ MLCP 


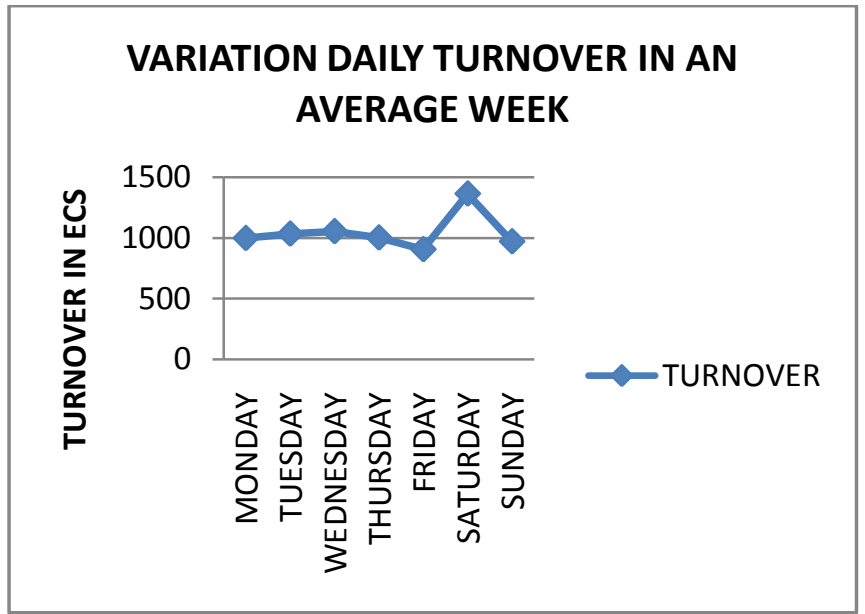

Fig 4.12 Parking Turnover Variations

\subsection{Opinion Surveys}

This section of the report elucidates the opinion of the user regarding parking problems faced by them, parking rates prevailing in the area, future parking charge system and parking fee to be charged. Opinion about willingness to pay for parking facilities, trip purpose, trip frequency, comfort level etc. was collected from both car users and non-car users. Car owners are those coming in cars, while non-car users are those who are coming in other modes which include two-wheelers, bus, by walk, etc. Opinion survey results are useful in deciding the parking charge system, parking fee etc. Total of 500 samples were done in and around the MLCP.

\subsubsection{Survey Findings @ MLCP}

All the graphs represent the average percentages of opinions of two wheeler and car users.

\subsubsection{Trip Purpose at Site}

Analysis of purpose of trip at the site revealed the following:-

The details of journey purpose are presented in

\section{Trip Purpose}

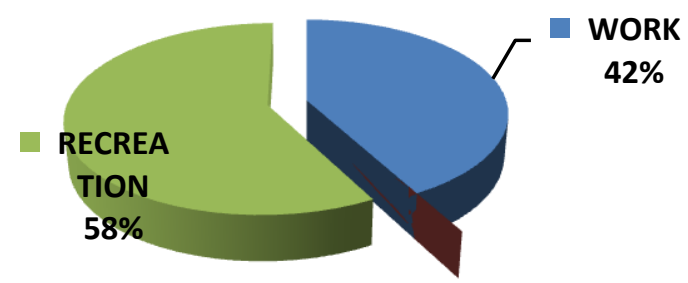

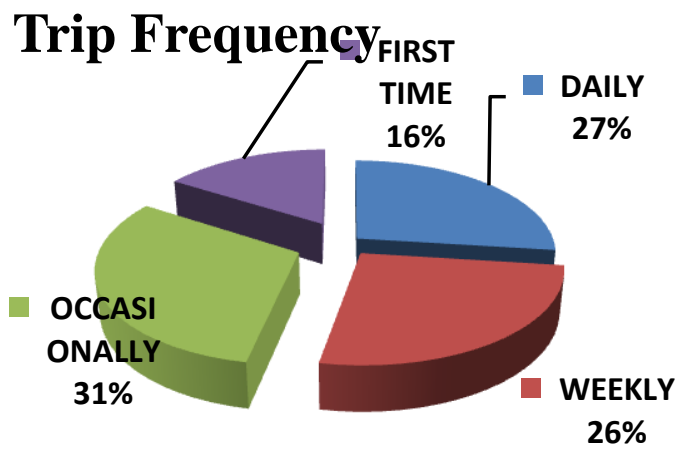

\subsubsection{Adequate Capacity at Site}

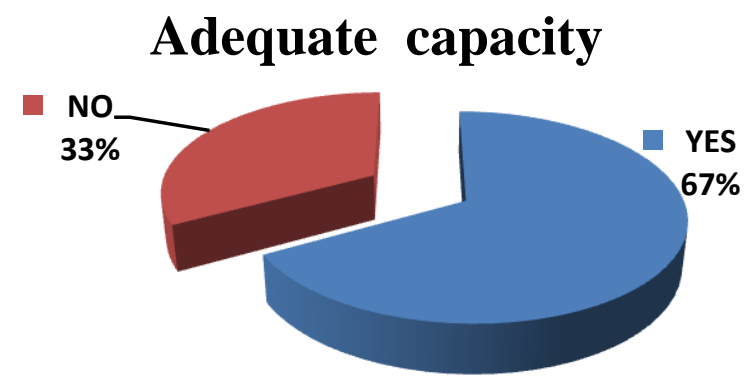

4.1.1.4 Affordability to Current Tariff Rates at Site

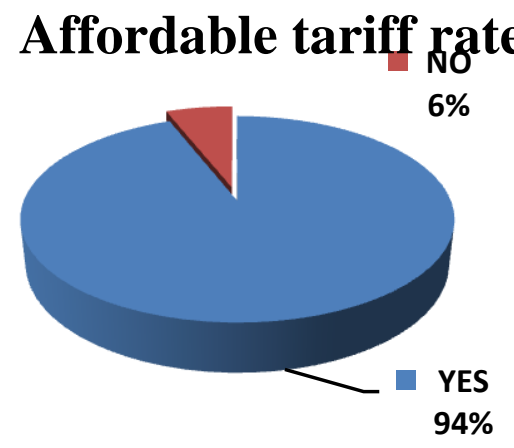

\subsubsection{Safety at Site}

Majority of the users both two wheelers and car .i.e. about $94 \%$ and $98 \%$ say that the MLCP has a very good safety system both in terms of parking Management ( security) and in case of any failure( fire disaster etc.).

\subsubsection{Trip Frequency at Site}

The trip frequency distribution of the survey is presented in Table and the average trip frequency distribution in percentage is shown in Figure below. 


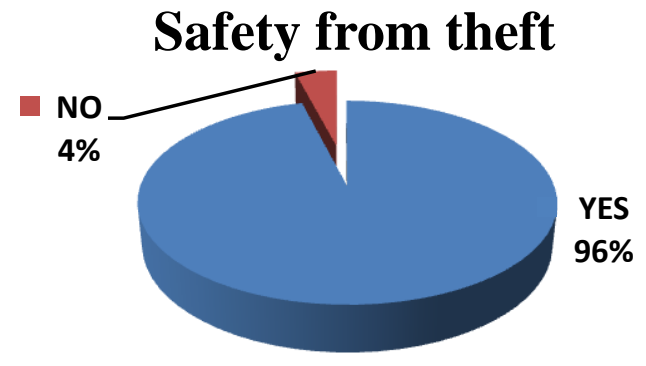

\subsubsection{Opinion Survey in the Study Area}

All the Graphs represented here are average percentages of two wheeler and four wheeler users.

\subsubsection{Trip Purpose in the Study Area}

Analysis of purpose of trip at the site revealed the following:-

\section{Trip Purpose}

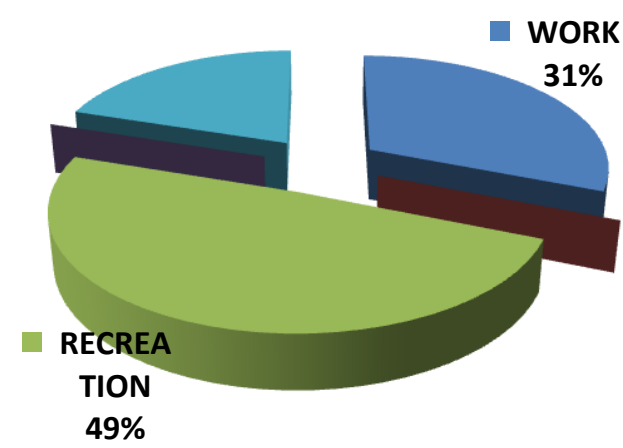

\subsubsection{Trip Frequency in the study area}

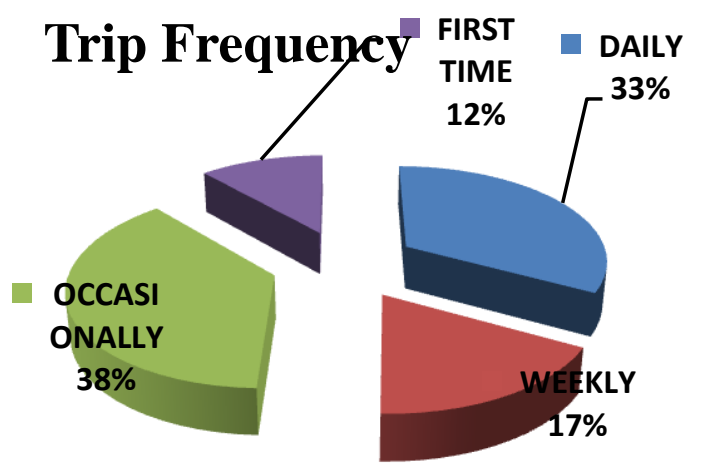

4.1.2.3. Adequacy of Parking in the Study Area

\section{Adequate capacity}

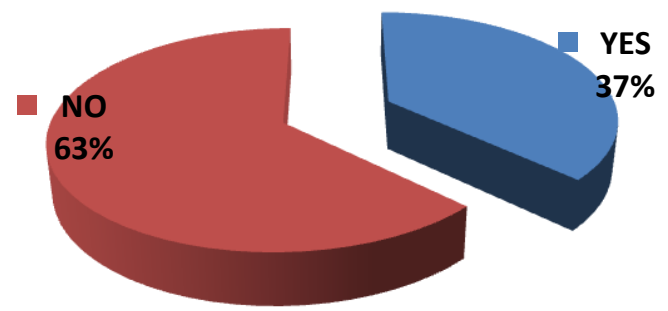

\subsubsection{Safety from Theft in the Study Area}

\section{Safety from theft}

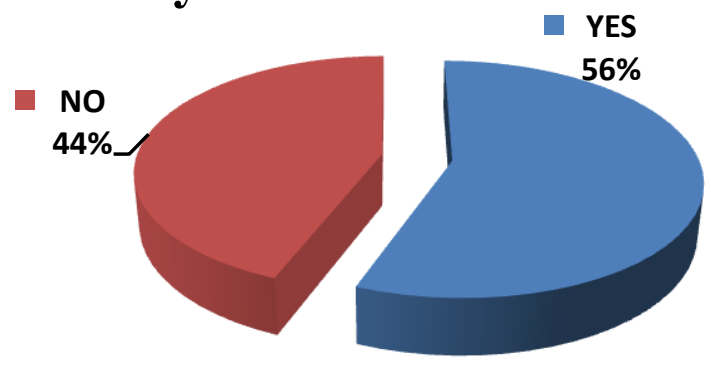

\subsubsection{Willingness to Pay in the Study Area}

The output of the surveys shows that $60 \%$ of car users are willing to pay rupees 10/- per hour for parking followed by $17 \%$ who are willing to pay rupees $15 /$ - per hour and $14 \%$ of the car users are willing to pay rupees 20/- per hour. Similarly, $62 \%$ of the two wheeler users are willing to pay rupees $5 /$ - per hour, $26 \%$ of them are willing to pay rupees $10 /$ - per hour and followed by $6 \%$ willinng to pay rupees $15 /$ per hour. Considering the fact that the parking pricing for two wheeler at the existing MLCP is rupees $2 /$ - per hour which $62 \%$ of the two wheelers are willing to pay for more efficient and safe paring which shows that the majority of the parkers can easily be shifted to the MLCP provided proper provision is provided at the MLCP. The average opinion of two wheeler and four wheeler users is presented below 


\section{Willingness to Pay}

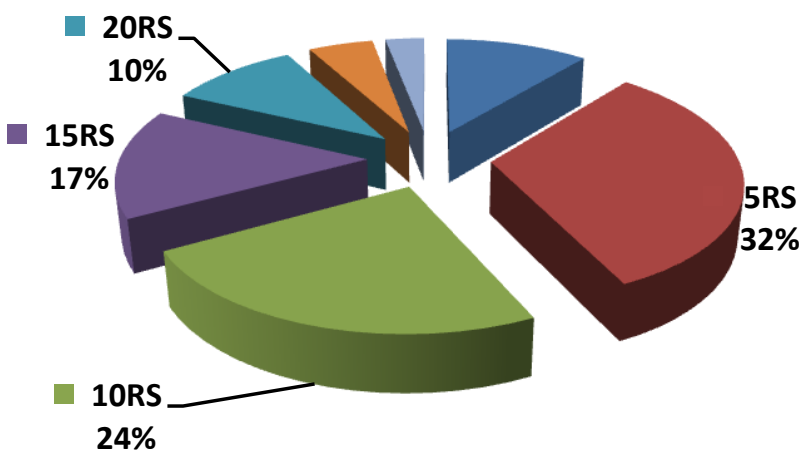

\subsubsection{Distance Willing to Walk to Parking lot in}

\section{the Study Area}

This is one of the most important criterions to be considered that how far the users are willing to cover the distance from the parked area to their destination point. Based on this consideration the adjacent roads with in the radius of 150200 meters need to prohibit on-street parking and the parking should be shifted to the MLCP.

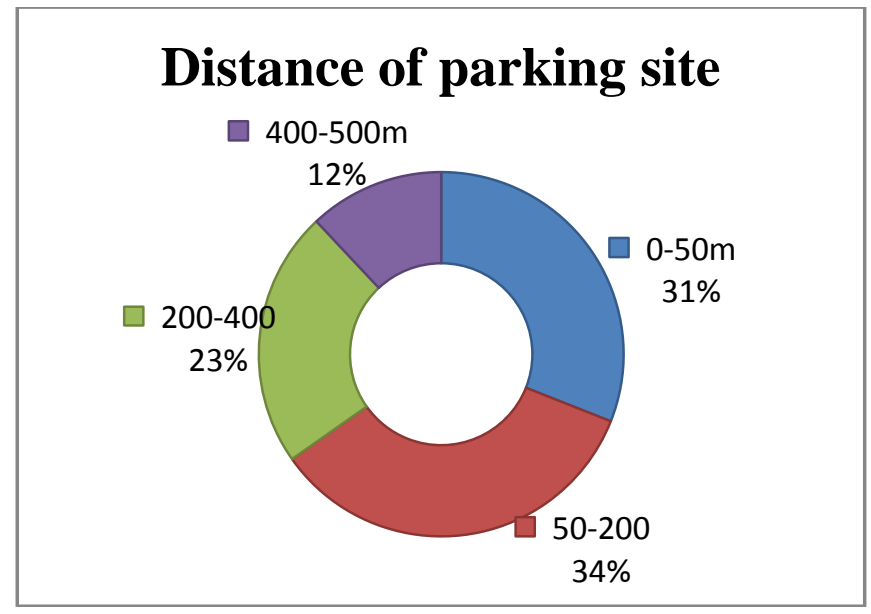

\section{FUTURE CONDITIONS}

\subsection{Estimation of Parking Demand}

This section estimates the future parking demand for the area and assesses whether the site can handle the unattended parking demand. The data regarding number of employees, sq. footage and other base information for the study area, could not be collected adequately by the survey teams due to security restrictions during the course of the surveys at study Sites. It was the sheer reluctance of the local people to part with information during the survey period that led a situation where desired data was unobtainable. In absence of sufficient data, future parking demand has been estimated as explained below.
- The potential of the Study area to attract higher footfalls in the future. Land use changes in the neighbourhood (getting more commercial)

- Vehicle ownership increases thereby same commercial area would attract more vehicles other things remaining the same.

\subsection{Attractiveness Factor}

It is the number of cars attracted (peak) to the area. This attractiveness factor is adjusted for the expected modal split for next five years. Redevelopments in the study areas and increase in the modal share of private vehicles in Bengaluru contributes to the assumptions of this factor. It also takes care of the suppressed demand that varies daily, and will vary seasonally and annually.

It is expected that the MLCP area will retain its pre-eminent position as a commercial and leisure destination primarily due to its commercial value for automobile shops.

\subsubsection{Expected Land use Change}

There are no significant upcoming developments in the vicinity of the site. So there does not seem to be any large change in land use in near future.

\subsubsection{Vehicle Ownership Increase}

Increase in vehicle ownership will increase the parking demand for an area.

\subsubsection{Assumptions}

- Attractiveness Factor: A factor of 1 is considered.

- Land Use Change: No change

- Average Vehicle Ownership Growth: 10\% till 2015 and two scenarios is considered i.e. 5\% and $10 \%$ for the year 2020 .

\subsubsection{Parking Turnover rate / yield}

It is the number of vehicles utilizing the available ECS in a unit time (usually considered for the entire day).

The mathematical equation for future parking demand is as below

Yield=Total observed daily Turnover/Peak hour parking demand

Yield = Total observed Daily Turn Over $/$ Peak hour parking demand (1)

Parking demand depends on the following: 
Available Capacity $=$ Assumed Yield $x$ Total parking supply available

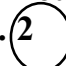

Assumed yield here is the rounded value of the yield obtained from ..........1

Future Parking demand $=$ Total Observed daily turnover (1+Vehicle Growth) n

1- $\quad$ Represents the existing situation n- Number of years.

Percentage of Parking Space availability

= 1-(Existing observed Turn over $/$

Maximum Capacity of MLCP w.r.t

existing yield)

\subsubsection{Summary of Parking Demand Scenario for}

\section{Future Horizon Year 2020, 2025 and 2030.}

\subsubsection{Summary of Parking Demand Scenario for a}

\section{Typical Weekday}

As per the analysis shown for future estimation and projection of parking demand for weekday at the site and the adjoining roads, it is observed that the yield at site is about 1.8 per ECS and 1.5 per ECS in the adjoining roads. The assumed vehicle growth rate of $10 \%$ (as per the Bengaluru CTTP report) is considered and the forecasted parking demand for the year 2020at the site is 1867 ECS and 6023ECS at the adjoining roads. Similarly after 2020 the forecasted parking demand for the year $\mathbf{2 0 2 5}$ at the site is 3007 ECS and 9701 ECS at the adjoining roads. Further after $\mathbf{2 0 2 5}$ the forecasted parking demand for the year $\mathbf{2 0 3 0}$ at the site is 4843 ECS and 15623 ECS at the adjoining roads.

Available capacity of the site with respect to yield is $\mathbf{1 0 0 0}$ ECS and 934 ECS at the adjoining roads. Considering the current year's peak parking demand at the site with 570 and the supply of $500 \mathrm{ECS}$ on a particular weekday, the availability of parking space is about $\mathbf{- 5 \%}$ (.i.e.-27 ECS) and the forecasted space availability in the year 2020, 2025 and $\mathbf{2 0 3 0}$ at the site will be $\mathbf{- 8 7 \%}$ (.i.e. $-434 \mathrm{ECS}$ ), $\mathbf{- 2 0 1 \%}$ (i.e. -1004 ECS). Thus it clearly shows that there is saturated space at the MLCP in the coming years during the weekdays.
Whereas when compare to the adjoining roads the current availability of parking space is (minus)-264\%(i.e.$1691 \mathrm{ECS})$ with supply of 640 ECS and peak hour demand of $3400 \mathrm{ECS}$ for the current year , (minus) $\mathbf{- 5 4 5 \%}$ (.i.e. 3490 ECS) for the year $\mathbf{2 0 2 0}$ and (minus) $\mathbf{- 9 3 9 \%}$ (.i.e. 6011ECS) for the year $\mathbf{2 0 2 5}$ and (minus) -1574\%(i.e. -10071 ECS) for the year 2030. This indicates that the adjoining roads are over saturated and cannot take up the parking load on the streets.

\subsubsection{Summary of Parking Demand for a Typical}

\section{Weekend}

As per the analysis for future estimation and projection of parking demand for weekend, at the site and the adjoining roads, it is observed that the yield at site is about 2.3 per ECS and 1.5 per ECS in the adjoining roads. The vehicle growth rate is assumed to be $10 \%$ till 2030. The forecasted parking demand for the year 2020at the site is 2415 ECS at site and 3720 ECS at the adjoining roads and for the forecasted parking demand for the year 2025 are 3889 ECS at site and $5992 \mathrm{ECS}$ at the adjoining roads and similarly for the year 2030 are 6263ECS at site and 9649 ECS at the adjoining roads. Available capacity with respect to the assumed yield is 1300ECS and 809 ECS.

Considering the current year's peak parking demand at the site with 603 ECS and the supply of 500ECS on a particular weekend, the availability of parking space is about $-5 \%$ (.i.e. -24 ECS) and the forecasted space availability in the year 2020,2025 and 2030 at the site will be $-86 \%$ (i.e.-429ECS), 199\%(i.e.-996ECS) and -526\%(i.e.2631 ECS) respectively. Thus it clearly shows that the MLCP 11 be fully saturated in the coming years during the weekends.

Whereas when compare to the adjoining roads the current availability of parking space in the current year is $160 \%$ (.i.e.-1021 ECS) with supply of 640 ECS and peak hour demand of $1661 \mathrm{ECS}$ and-360\% (.i.e. -2303 ECS) for the year 2020 and (minus) $-640 \%$ (.i.e. -4099) ECS will be required)for the year 2025.Further $-1093 \%$ (i.e.6992 ECS) for the year 2030. This indicates that the adjoining roads will be over saturated by 2030 and cannot take up the parking load on the streets.

The analysis of a typical weekday and a typical weekend states that the MLCP and the adjoining roads are over saturated and there is a no space available for parking neither on streets nor at MLCP. 


\section{ECONOMICAL APPRAISAL}

\subsection{Economical Evaluation}

\subsubsection{Parking Charges at MLCP}

The parking charges for two wheelers and four wheelers based on the parking duration is as shown in Table 6.1

Table 6.1 Parking Charges at MLCP

\begin{tabular}{|l|l|l|}
\hline Duration & $\begin{array}{l}\text { Two } \\
\text { wheelers }\end{array}$ & $\begin{array}{l}\text { Four } \\
\text { wheelers }\end{array}$ \\
\hline $0-0.5 \mathrm{hr}$ & 2 & 6 \\
\hline $0.5-1 \mathrm{hr}$ & 3 & 12 \\
\hline $1-3 \mathrm{hr}$ & 5 & 23 \\
\hline $3-5 \mathrm{hr}$ & 10 & 35 \\
\hline $5-12 \mathrm{hr}$ & 25 & 85 \\
\hline$>12 \mathrm{hrs}$ & $\begin{array}{l}25+\text { Cycle } \\
\text { Repeats }\end{array}$ & $\begin{array}{l}85+\text { Cycle } \\
\text { repeats }\end{array}$ \\
\hline
\end{tabular}

\subsubsection{Revenue collected at MLCP}

Based on the Parking Charges for two wheelers and four wheelers and the parking Turnover the revenue generated at MLCP is as shown in Table 6.2and Considering 52 Weeks in a typical year and assuming uniform Turnover and Revenue generation Throughout the year, the turnover and total revenue generated for a year is as shown in Table 6.3

Table 6.2 Parking Turnover and Revenue for a typical Week in a year

\begin{tabular}{|l|c|c|c|c|}
\hline & \multicolumn{2}{|l|}{ Two wheelers } & \multicolumn{2}{l|}{ Four wheelers } \\
\hline Days & $\begin{array}{l}\text { Turnover } \\
\text { (ECS) }\end{array}$ & $\begin{array}{l}\text { Revenue } \\
\text { (Rupees) }\end{array}$ & $\begin{array}{l}\text { Turnover } \\
\text { (ECS) }\end{array}$ & $\begin{array}{l}\text { Revenue } \\
\text { (Rupees) }\end{array}$ \\
\hline Monday & 329 & 2501 & 914 & 26326 \\
\hline Tuesday & 354 & 2609 & 937 & 27001 \\
\hline Wednesday & 338 & 2623 & 969 & 27896 \\
\hline Thursday & 369 & 2835 & 909 & 26324 \\
\hline Friday & 345 & 3016 & 818 & 23579 \\
\hline Saturday & 420 & 3100 & 1253 & 34174 \\
\hline Sunday & 395 & 3173 & 872 & 25114 \\
\hline Average & $\mathbf{2 5 5 0}$ & $\mathbf{1 9 , 8 5 7}$ & $\mathbf{6 6 7 2}$ & $\mathbf{1 , 9 0 , 4 1 4}$ \\
\hline
\end{tabular}

Table 6.3 Parking Turnovers and Revenue for a Typical Week and a Year

\begin{tabular}{|c|c|c|}
\hline DURATION & $\begin{array}{c}\text { TURNOVER } \\
\text { (ECS) }\end{array}$ & $\begin{array}{c}\text { REVENUE } \\
\text { (RUPEES) }\end{array}$ \\
\hline 1WEEK & $\mathbf{7 3 0 9 . 5}$ & $\mathbf{2 , 1 0 , 2 7 1}$ \\
\hline 1YEAR & $\mathbf{3 8 0 0 9 4}$ & $\mathbf{1 , 0 9 , 3 4 , 0 9 2}$ \\
\hline
\end{tabular}

\subsubsection{Parking Demand and Supply}

The Parking Demand and Supply at the site as well as in the study area for the present horizon year 2014 and forecasted values for the future years 2020, 2025 and 2030 are as shown in Table 6.4

Table 6.4 Parking Demand and supply for future years

\begin{tabular}{|c|c|c|c|c|}
\hline \multirow{2}{*}{$\begin{array}{l}\text { Horizon } \\
\text { Year }\end{array}$} & \multicolumn{2}{|c|}{ MLCP } & \multicolumn{2}{|c|}{ ADJOINING ROADS } \\
\hline & $\begin{array}{l}\text { Demand } \\
\text { (ECS) }\end{array}$ & $\begin{array}{l}\text { Availability } \\
\text { (ECS) }\end{array}$ & $\begin{array}{l}\text { Demand } \\
\text { (ECS) }\end{array}$ & $\begin{array}{l}\text { Availability } \\
\text { (ECS) }\end{array}$ \\
\hline 2014 & 1209 & -26 & 2750 & -1356 \\
\hline 2020 & 2141 & -432 & 4872 & -2897 \\
\hline 2025 & 3448 & -1000 & 7847 & -5055 \\
\hline 2030 & 3374 & -2277 & 12636 & -8532 \\
\hline
\end{tabular}

\subsubsection{Proposal for additional floors}

It can be seen from the Table 6.4 that the MLCP is not able to cater the present Parking Demand and it gets fully saturated by the year 2030.Hence to cater the demand for at least few years an additional of two floors is proposed if the Structural stability criteria is satisfied.

\subsubsection{Proposal of new MLCP}

From the Table 6.4 it is also clear that the on street parking demand is too high for the present also for the future years and the available on street and off street parking supply in the study area is not sufficient to cater the present and future demand and also the congestion on roads would be too high if more on street parking supply is created, hence another MLCP can beinstalled at a suitable location in the study area.

\subsection{Economic Viability}

Economic Viability for the new proposals is worked out using Benefit Cost Ratio (B/C ratio) as follows Assumptions:
i) Total area of present $\mathrm{MLCP}=\mathbf{3 2 , 4 9 0 s q f t}$
ii) Cost of construction= Rs.1500/sqft
iii) Maintenance cost $\mathbf{5} \mathbf{5 \%}$ of Construction cost
Benefit-Cost Ratio: 


\begin{tabular}{|l|l|l|}
\hline & \multicolumn{1}{|c|}{ A) COSTS } & $\begin{array}{l}\text { AMOUNT } \\
\text { (Million) }\end{array}$ \\
\hline i & Cost of Construction/floor & 48.735 \\
\hline ii & Cost of Construction for 2 floors & 97.47 \\
\hline iii & Maintenance cost/year & 2.44 \\
\hline iv & Maintenance cost for 20 years & 48.74 \\
\hline v & TOTAL COSTS & $\mathbf{1 4 6 . 2 1}$ \\
\hline & \multicolumn{1}{|c|}{ B) BENEFITS } & \\
\hline i & Revenue by redesign of building,etc & 6.13 \\
\hline ii & Revenue by construction new 2floors & 6.45 \\
\hline iii & Total revenue & 12.58 \\
\hline iv & Revenue for 20years & 251.60 \\
\hline v & $\begin{array}{l}\text { Revenue due to escalation of parking } \\
\text { charges by 5\% }\end{array}$ & 12.58 \\
\hline vi & TOTAL BENEFIT & $\mathbf{2 6 4 . 1 8}$ \\
\hline & & \\
\hline & BENEFIT/COST RATIO & $\mathbf{1 . 8 1}$ \\
\hline & \multicolumn{2}{|l|}{} \\
\hline
\end{tabular}

$\mathrm{B} / \mathrm{C}$ ratio is greater than 1 , hence the proposals are worthwhile.

\section{DISCUSSIONS AND CONCLUSIONS}

i) Due to on-street parking the carriage way of all the surrounding roads has been reduced. Hence the on street parking has to be prohibited in the surrounding area thereby increasing the V/C ratio.

ii) From the opinion Survey the commuters doesn't will to walk a distance more than $250 \mathrm{~m}$ from the parking area due to which unauthorised parking is increasing. Hence parking needs to be scientifically regulated.

iii) To increase the $\mathrm{V} / \mathrm{C}$ ratio of all the roads in vicinity of the MLCP the Street Hawkers, Haphazard type of parking, Footpath parking, unauthorised parking, Auto stand at the junctions have to be regulated to reduce congestion and accidents.

iv) The parking fee has to be revised in case of this MLCP as it is fully owned by BBMP the charges are very low, thus leading to low revenue to BBMP. The parking charges should be as per the prevailing market price for parking.

v) On-street parking will have to be charged with higher parking fees than the MLCP. The main idea behind this is to discourage use of private vehicles and promote public transport system.

vi) Two wheeler parking on the adjacent cross roads around in the radius of $100 \mathrm{~m}$ to the MLCP needs to be completely prohibited. The road width of this cross roads is less than 5 meters and two wheeler parking takes way about 2 meter space of the carriage way leading to traffic congestion in the cross roads.

vii) Current Year, 2014: As per the surveys and analysis, the capacity of the MLCP calculated based on current peak hour parking demand and the current dailyturnover is 1054ECS during a weekday and 1363ECS during Weekend. The analysis in the preceding chapter shows that the MLCP has insufficient car parking space to cater the present parking demand. i.e. in the current year, the parking demand is 570 ECS at the MLCP and 2331 ECS at the adjacent roads during the weekdays and similarly, the parking demand is 603 ECS at the MLCP and 1661 ECS at the adjacent roads during the weekends. At this parking demand and shift of on-street parking in to the MLCP, the MLCP will have insufficient parking space available .i.e. during the weekdays it is expected to be $-345 \%$ (.i.e. $1727 \mathrm{ECS}$ ) require in additional and during the weekends it is nearing to $-166 \%$ (.i.e.832ECS) availability of parking space. The yield of 2during the weekdays and 1.5 during the weekends have been considered.

Hence to cater this Demand MLCP should be redesigned or renovated as per standards with proper parking bay dimensions and utilising the ramps on BV K Iyengar road side which are not used for the purpose and making the optimal usage of complete space demand can be catered to some extent.

viii) Horizon Year 2020: Considering a constant vehicle growth rate of $10 \%$ till the year 2020, the parking demand at the MLCP is expected to rise to 1867ECS and 6023ECS at the adjacent roads during the weekdays. Similarly, the demand would increase to2415 ECS at MLCP and 3720 ECS at the adjacent roads during the weekends. At this parking demand and the shift of on-street parking into the MLCP, the MLCP will have insufficient parking spaces available during the weekday's .i.e. around $-689 \%$ space will be required which is 3445 ECS. However during the weekends a slight parking less additional spaces needed i.e. about $372 \%$ which constitutes to about $1860 \mathrm{ECS}$ which is still needed by implementing parking management plans and enforcement.

Hence to accommodate this demand an additional of two to three floors could be constructed which is economically viable as per the analysis done in chapter 6 for this the structural stability of the foundation, SBC of the soil, By Laws have to be considered.

ix) Horizon Year 2025: Considering the vehicle growth rate of $10 \%$ annually, the parking demand at MLCP in the year 2025 is most likely to be around 3007 ECS during the weekdays and 3889 ECS in the weekends. Similarly at the adjacent roads the parking demand may move up to 9701ECS during weekdays and 5992 ECS during the weekends. This shows that in the year 2025 the MLCP would reach its maximum over saturated capacity. Similarly, the adjacent roads would get over saturated. Hence on-street parking could be allowed during the weekends with much higher parking price than the parking price at MLCP. 
x) Horizon Year 2030: Considering the vehicle growth rate of $10 \%$ annually, the parking demand at MLCP in the year 2030 is most likely to be around 4843ECS during the weekdays and 6263 ECS in the weekends. Similarly at the adjacent roads the parking demand may move up to 15623ECS during weekdays and 9649ECS during the weekends. This shows that in the year 2030 the MLCP would reach its maximum over saturated capacity. Similarly, the adjacent roads would get over saturated. Hence on-street parking could be allowed during the weekends with much higher parking price than the parking price at MLCP.

Hence with the demand analysis for future forecasting the present MLCP will not withstand the demand of parking so need a new MLCP at this area of study.

\section{REFERENCES}

[1] Wilbur Smith Associates, Inc., "Development of Multilevel parking facilities in Greater Mumbai", October 2008

[2] Directorate of Urban Land ,"Policy Paper for Parking, In the Bangalore Metropolitan Region", Version 1 ,October 2008

[3] KSIIDC -IL \& FS project development "Final prefeasibility report for development of MLCP facilities" ,October 2009

[4] Bangalore Development Authority, "Zoning of land use and regulations", Revised Master Plan ,Volume III ,2007

[5] Kadiyali.L.R, "Traffic Engineering and Transportation Planning", Khanna Publishers, Third Edition 2002.

[6] Khanna S. K \& Justo C.E.G, "Highway Engineering", Nem Chand \& Bros, Roorkee (U.A), Eighth Edition 2001

[7] National Urban Transport Policy for India, Ministry of Urban Development, Government of India, April 2006.

[8] Indian Road Congress, "Tentative Recommendations on the provision of parking spaces for urban areas", IRCSP12-1973.

[9] "Parking Management Strategies, Evaluation and Planning," -Todd Litman Victoria Transport Policy Institute February 2011.

[10] "Parking Study on Main Corridors in Major Urban Centre," an International Journal of Modern Engineering Research (IJMER) Vol.2, Issue.3, MayJune 2012.

[11] "Downtown Parking Facility and Management Study", Prepared for the City of Dover, NH, and March, 2008.

[12] "Traveller response to transportation system changes," transportation research board Washington, D.C. 2003.

[13] "A Reservation-based Smart Parking System," by Hongwei Wang, University of Nebraska - Lincoln, 7-12011.

[14] "Parking supply and demand analysis," city of Portsmouth, January 2012.
[15]"Addendum existing and future parking supply and demand analysis," submitted to the city of Lexington desman April 2010.

[16] Mott MacDonald ,"Kings Lynn Town centre parking Study", October 2001

[17] Dr T S Reddy and Dr S A Jalihal "Parking Management Strategy for the Walled City of Jaipur", CRRI, New Delhi, September 28, 2001

[18] "Traffic Engineering-An Introduction" by GR WELLS, 1970. 